\title{
Selenium and mercury in the hair of raccoons (Procyon lotor) and European wildcats (Felis s. silvestris) from Germany and Luxembourg
}

\author{
Danuta Kosik-Bogacka (1) ${ }^{1} \cdot$ Natalia Osten-Sacken ${ }^{2,3} \cdot$ Natalia Kanocha-Arendarczyk $^{4} \cdot$ Karolina Kot $^{4}$. \\ Bogumiła Pilarczyk ${ }^{5} \cdot$ Agnieszka Tomza-Marciniak $^{5} \cdot$ Joanna Podlasińska $^{6} \cdot$ Mateusz Chmielarz $^{4} \cdot$ Mike Heddergott $^{7}$. \\ Alain C. Frantz ${ }^{7} \cdot$ Peter Steinbach $^{8}$
}

Accepted: 4 October 2019 / Published online: 16 November 2019

(c) The Author(s) 2019

\begin{abstract}
This study examined the concentration of total mercury (THg) and selenium (Se), as well as the molar ratio of Se:THg in hair samples of terrestrial animals. THg and Se concentrations were measured from the hair of raccoons (Procyon lotor) and European wildcats (Felis s. silvestris) from Germany and Luxembourg. Median THg concentrations in hair from raccoons and wildcats were 0.369 and $0.273 \mathrm{mg} \mathrm{kg}^{-1}$ dry weight (dw), respectively. Se concentrations were higher in the hair of raccoons than of wildcats ( 0.851 and $0.641 \mathrm{mg} \mathrm{kg}^{-1} \mathrm{dw}$, respectively). Total mercury concentration in hair of raccoons from Luxembourg was almost $5 \times$ higher that found in hair of raccoons from Germany; however, Se concentration was similar. Thus, molar ratio of Se:THg was $\sim 4 \times$ higher in the hair of raccoons from Germany than those from Luxembourg. Significant negative correlation was found between THg concentration and Se:THg molar ratio in both wildcats and raccoons.
\end{abstract}

Keywords Hair $\cdot$ Total mercury $\cdot$ Selenium $\cdot$ Raccoon $\cdot$ European wildcat

\section{Introduction}

Mercury $(\mathrm{Hg})$ is a chemical element with well-established toxic effects on humans and other terrestrial mammals, reaches its highest concentrations in predatory fish, piscivorous birds, and mammals (Eisler 2000; Scheuhammer et al. 2007; Wiener et al. 2003). Terrestrial vertebrates can absorb $\mathrm{Hg}$ through their skin, respiratory, and digestive systems (Graeme and Pollack 1998). Mercury accumulates in internal organs, especially the brain, causing neurotoxicity and impairing development (Castoldi et al. 2001; Davis

Danuta Kosik-Bogacka

kodan@pum.edu.pl

Independent of Pharmaceutical Botany, Department of Biology and Medical Parasitology, Pomeranian Medical University in Szczecin, Powstanców Wielkopolskich 72, 70-111

Szczecin, Poland

2 Institute of Veterinary Medicine, Faculty of Biological and Veterinary Sciences, Nicolaus Copernicus University, Gagarina 7, 87-100 Torun, Poland

3 Fondation faune-flore, 25 rue Muenster, L-2160 Luxembourg, Luxembourg

4 Department of Biology and Medical Parasitology, Pomeranian et al. 1994; Graeme and Pollack 1998). Selenium (Se) is an essential micronutrient for humans and animals (Fordyce 2013; Mao et al. 2016; Thomson 2004). It has numerous important biological functions, serving as the active center of selenoenzymes and selenoproteins, playing an integral role in energy metabolism and gene expression, and functioning in multiple antioxidant, immunoregulatory, and antagonistic roles (Izquierdo et al. 2010; Roman et al. 2014). Selenium has long been recognized for its potential in reducing the toxicity of $\mathrm{Hg}$ compounds and has been postulated as a core element in the in vivo demethylation

Medical University in Szczecin, Powstanców Wielkopolskich 72, 70-111 Szczecin, Poland

5 Department of Animal Hygiene and Prophylaxis, West Pomeranian University of Technology, Judyma 6, 71-466 Szczecin, Poland

6 Department of Ecology, Environmental Management and Protection, West Pomeranian University of Technology, Słowackiego 17, 71-434 Szczecin, Poland

7 National Museum of Natural History, 25 Rue Münster, 2160 Luxembourg, Luxembourg

8 University of Göttingen, Faculty of Chemistry, Tammannstraße 4, 37077 Göttingen, Germany 
pathway of methylmercury (Bjørklund et al. 2017; Khan and Wang 2010). In animals, interactions between $\mathrm{Hg}$ and Se depend mainly on the chemical form and concentration of both elements in the environment duration of exposure, and the species in question (Bjerregaard et al. 2011; CuvinAralar and Furness 1991). A possible pathway for the in vivo demethylation of methylmercury $(\mathrm{MeHg})$ involving $\mathrm{Se}$ compounds has been observed, producing the $\mathrm{Hg}-\mathrm{Se}$ complex as its final degradation product (Khan and Wang 2010). The Hg-Se complex has been observed in the liver, kidney, and brain of marine mammals indicating that this pathway may be active (Lailson-Brito et al. 2012). The Hg: Se molar ratio in animal tissues is an intensively investigated parameter in laboratory and field studies (CuvinAralar and Furness 1991; Raymond and Ralston 2004). Although numerous studies indicate that Se protects against $\mathrm{Hg}$ toxicity, studies have also documented that $\mathrm{Hg}$ exposure reduced the activity of Se-dependent enzymes and suggested a role of $\mathrm{Hg}-\mathrm{Se}$ interactions in developmental pathophysiology (Ohlendorf and Heinz 2011; Raymond and Ralston 2004). Nonetheless, this ratio is commonly used to evaluate the susceptibility of animals to $\mathrm{Hg}$ toxicity.

Most studies have measured $\mathrm{Hg}$ and Se concentrations in internal mammalian tissues, such as the liver and kidney, but there exist effective non-invasive methods for bioindication studies utilizing cutaneous tissues, such as hair, fur and wool. It has been shown that total $\mathrm{Hg}$ concentration ( $\mathrm{THg}$ ) in hair is highly correlated with $\mathrm{THg}$ in blood and is thought to be marker of THg levels in circulation (Castellini et al. 2012; Lieske et al. 2011; Rea et al. 2013).

Similar relationships are observed in the case of Se. For this reason, some researchers indicate that Se concentration in animal hair may be successfully used to diagnose both deficiency and a high level of this elements in the organism (Clark et al. 1989, Pilarczyk et al. 2019). In the available literature there are a lot of works indicating that hair is useful non-invasive matrice for Se biomonitoring in animal and human body. For example, Górski et al. (2018) found that increase oral intake of Se caused a significant increase $(p \leq 0.05)$ in the Se concentration in the hair of animals. In turn, Cho and Yang (2018), based on their observation, suggested that hair better reflects Se status in organism than serum and therefore they recommend use of hair, as one of matrixes, to full analysis of selenium status. In addition, significant correlations between $\mathrm{Se}$ and $\mathrm{Hg}$ in hair was reported (Soares de Campos et al. 2002).

Many medium sized mammals widely distributed in forest, agricultural and urban landscapes of the central Europe, with same species introduced into areas beyond their natural occurrence (Kalisińska 2019). Raccoons Procyon lotor (Linnaeus, 1758) are bioindicators of environmental contamination, including $\mathrm{THg}$, due to their omnivorous diets and dependence on both aquatic and terrestrial systems for food, making them susceptible to THg biomagnification from consumption of contaminated lower-trophic-level organisms (Bigler et al. 1975; Herbert and Peterle 1990; Lord et al. 2002). The raccoon is a Central and North American carnivore that was introduced into Germany around 70 years ago (Stubbe 1993). The role of the European wildcat (Felis silvestris Schreber, 1777), feeds animal prey, in bioindication has not yet been researched. The distribution area of the European wildcat, a mediumsized carnivore is composed of disconnected populations extending from the Iberian Peninsula over southern and central Europe into eastern Europe (Herrmann et al. 2007; Klar et al. 2008). The wildcat is one of the most endangered carnivore species in Europe. The population density declined and the distribution area became fragmented over the last century due loss of habitat, illegal hunting and road kills (Sahl and Artois 1994). The wildcat is a solitary and territorial species and home areas are quite big, range from 175 ha to more than 2000 ha, higher for males (Biró et al. 2004). Fragmentation of the natural habitat can influence migration and possibilities of finding new areas for young individuals. Some treat for young cats are also larger predators, such as foxes, wolves, other cats, and large birds of prey, such as owls and hawks, however adults are secretive and agile and can protect themselves from animals larger than themselves (Nowak 1997). Another treat for wild living populations is mixing with domestic cats and wildcat is facing similar threats across its range in mainland Europe (Pierpaoli et al. 2003). Such genetic mixing may result in individuals that are less well adapted (Rhymer and Simberloff 1996).

The size of the animal population depends on their reproductive success, and it depends on many factors, including exposure to harmful compounds or mineral deficiencies. Excessive $\mathrm{Hg}$ and $\mathrm{Se}$ concentration in animals results in disturbances in reproduction. In case of $\mathrm{Hg}$, the negative relationship between $\mathrm{Hg}$ concentrations and the propensity and ability of adult females to reproduce was reported (Beau et al. 2019). These disorders are explained by endocrine disruptive properties of $\mathrm{Hg}$. In turn Silva et al. (2019) reported that even environmental levels of $\mathrm{Hg}$ affects spermatozoa function and fertility capacity in sperm. Also, Se deficiency is related to the problem of reproduction in both males (Ahsan et al. 2014) and females (Qazi et al. 2018).

Considering that $\mathrm{Se}$ is capable of metabolic interaction with $\mathrm{Hg}$, it seems to be interesting to assess molar concentrations of $\mathrm{THg}$ in relation to $\mathrm{Se}$ concentration in raccoons (omnivores) and wildcats (carnivores). Though wellstudied in piscivorous animals, reports on the hair levels of $\mathrm{THg}$ and $\mathrm{Se}$ and the interactions between them in raccoons and wildcats are currently missing from European literature. Therefore, the aim of the study was to investigate the 
concentration of $\mathrm{THg}$ and $\mathrm{Se}$, and $\mathrm{Se}: \mathrm{THg}$ molar ratio in hair samples taken from raccoons and wildcats.

\section{Material and methods}

\section{Areas of study}

Samples were collected from three areas in Germany (Hesse, Saxony and Baden-Württemberg) and one area in Luxembourg (Fig. 1). The first of the areas studied corresponded to the city of Kassel $\left(106.78 \mathrm{~km}^{2}\right)$, the largest city in the northern state of Hesse $\left(51^{\circ} 18^{\prime} \mathrm{N}, 9^{\circ} 29^{\prime} \mathrm{E}\right)$. The city is located in an extended valley on the flood plain of the Fulda cap River lowercase due to its geographical location in the valley, the Fulda often floods into Kassel and adjacent urban areas. Almost half of this area is cultivated (construction area $35 \%$ and transport $13 \%$ ) and $32 \%$ of the area is forest, park and green areas. The expansion of the city in the 20th century saw the settlement and expansion of heavy industry, mechanical and automotive engineering, and the arms industry.

The second investigation area, Mücka, is a small Upper Lusatian municipality in the Saxony district of Görlitz (51 ${ }^{\circ}$ $\left.18^{\prime} \mathrm{N}, 14^{\circ} 42^{\prime} \mathrm{E}\right)$. Mücka is located in the center of the large $300 \mathrm{~km}^{2}$ forest and pond-rich landscape of the biosphere reserve Oberlausitzer Heide- und Teichlandschaft. This is the most pond-rich area in Germany with about $50 \%$ forest and $27.5 \mathrm{~km}^{2}$ comprised of ponds, streams and other waters. This area is characterized by riparian forests, moor, pagan, and dune landscapes. Mücka is located $15 \mathrm{~km}$ southeast of the Boxberg power plant, a brown coal power plant in the Lusatian brown coal mining district, which, according the 2016 reporting year, had mercury emissions of $512 \mathrm{~kg}$ per year (www.thru.de).

The small town of Geislingen an der Steige $\left(75.83 \mathrm{~km}^{2}\right)$ is located on the edge of the Middle Swabian Jura in the district of Göppingen, in Baden-Württemberg $\left(48^{\circ} 37^{\prime} \mathrm{N}, 9^{\circ}\right.$ $\left.49^{\prime} \mathrm{E}\right)$. The city is located in the Fils River valley, where they experience occasional flooding. The study area is mainly characterized by agricultural land $(52 \%)$ and forest (33\%). The settlement area covers about $7 \%$ and water $<1 \%$ of the area.

Luxembourg is one of the smallest European countries with an area of $2.586 \mathrm{~km}^{2}$. The north of the country (Oesling) is a part of the Ardennes and is characterized by wooded mountains, hills, and deep river valleys. In the south and center of the country is the Gutland region, comprising $68 \%$ of the Luxembourg territory. Forests and agricultural areas cover $85 \%$ of the total land. Most industry in Luxembourg is found in Gutland. In addition to a large iron mill in Differdange, there are also companies producing chemical goods (such as car tires, plastics (synthetic materials), synthetic fibers, glass, ceramics). An investigation of four fish species from seven rivers (Syrbaach, Sûre, Our, Wark, Wiltz, Troine, Clerve) in northern Luxembourg (Oesling) showed mercury levels of 10.3 to $534.5 \mathrm{ng} \mathrm{g}^{-1}$ wet weight (wt) (Boscher et al. 1996).

\section{Animal hair sample preparation}

This study was performed on the carcasses of adult raccoons from Germany $(n=18)$ and Luxembourg $(n=10)$ and wildcats from Luxembourg $(n=15)$ collected between 2015 and 2016. The wildcats had been killed in traffic and the raccoons were legally hunted.

Samples of hair were collected from the back near the shoulder blades. Approximately $4 \mathrm{~g}$ of hair were collected from each animal. Samples were stored in polyvinyl bags until further processing. Hair samples weighing $0.5 \mathrm{~g}$ each were washed according to the International Atomic Energy Agency recommended procedure (IAEA 1978) with acetone, then deionised water, and then again with acetone to remove adhered dirt and organic materials. Hair samples were then dried in an oven at $110^{\circ} \mathrm{C}$ for $12 \mathrm{~h}$ (Curi et al. 2012).

\section{Hair THg and Se analysis}

Total mercury concentrations were determined using atomic absorption spectroscopy (AAS). The assays were run in an AMA 254 mercury analyzer (Altach Ltd, Czech Republic) in accordance with the procedure described by Lanocha et al. (2014). The detection limit for this device is $0.01 \mathrm{ng}$ THg. The analytical procedure was checked by determining THg concentrations in samples of two reference materials: DOLT-4 (Dogfish Liver Certified Reference Material for Trace Metals, Canadian Irradiation Centre, Laval, Quebec; $n=3$ ) and 8414 NIST (Bovine Muscle Powder National Institute of Standards and Technology NIST, Canada; $n=$ 5). The recovery rates were $99.2 \%$ and $108 \%$ for DOLT-4 and 8414 NIST, respectively.

Selenium concentrations were measured using spectrofluorimetry. Samples were digested in $\mathrm{HNO}_{3}$ at $230^{\circ} \mathrm{C}$ for $180 \mathrm{~min}$ and in $\mathrm{HClO}_{4}$ at $310^{\circ} \mathrm{C}$ for $20 \mathrm{~min}$. Then, $9 \% \mathrm{HCl}$ was added to reduce $\mathrm{Se}^{6+}$ to $\mathrm{Se}^{4+}$. Selenium was determined by reaction with 2,3-diaminonaphthalene (Sigma Aldrich) under controlled $\mathrm{pH}$ conditions ( $\mathrm{pH}$ 1-2) producing selenodiazole complex, which was then extracted into cyclohexane. More details of the analytical procedures are given by Pilarczyk et al. (2010). Selenium concentration was determined fluorometrically using a RF-5001 PC Shimadzu spectrophotofluorometer. The excitation wavelength was $376 \mathrm{~nm}$ and the fluorescence emission wavelength was $518 \mathrm{~nm}$. The detection limit of Se was $0.003 \mu \mathrm{g} \mathrm{g}^{-1}$. The procedure was validated with certified reference material 


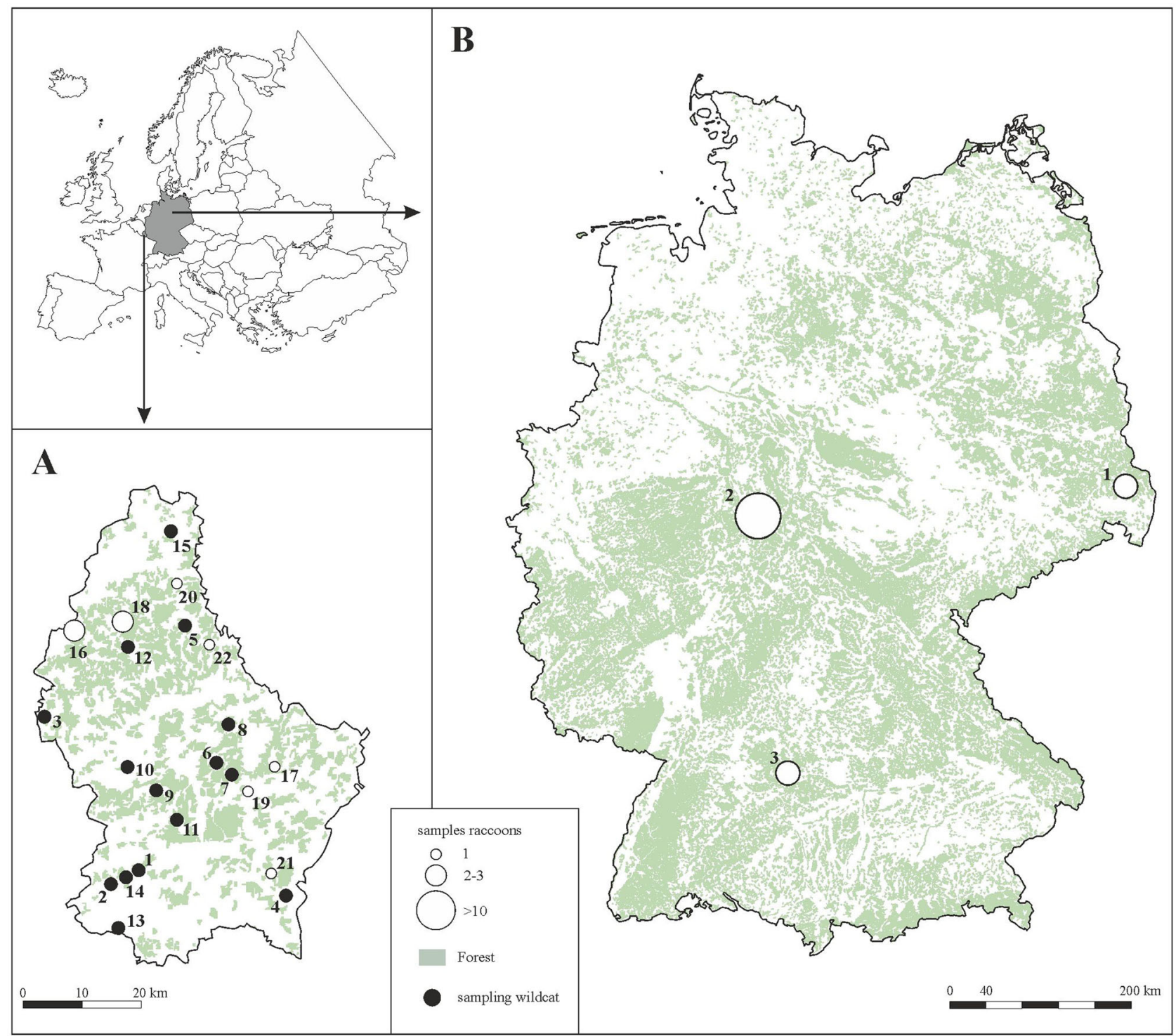

Fig. 1 Geographic distribution of the samples from European wildcats (Felis s. silvestris) in Luxembourg and raccoons (Procyon lotor) in Luxembourg and Germany. a Luxembourg. Wildcat (black circle): 1 $=$ Mamer; $2=$ Garnich; $3=$ Rombach; $4=$ Bous; $5=$ Hoscheid; $6=$ Angelsberg; 7 = Koedange; 8 Medernach; 9 Bour; $10=$ Rippweiler;

NCS ZC 71001 (bovine liver, China National Analysis Center for Iron and Steel, Beijing, China; $n=5$ ). The mean Se concentration was $90 \%$ of the reference value. Measured $\mathrm{Se}$ and $\mathrm{THg}$ concentrations were expressed as $\mathrm{mg} \mathrm{kg}^{-1}$ dry weight $(\mathrm{dw})$.

\section{Se:THg molar ratio calculation}

Dry weight measurements were converted to molar concentrations by the following formula: molar concentration $\left(\mathrm{nmol} \mathrm{g}^{-1}\right)=$ concentration $\left(\mathrm{nmol} \mathrm{g}^{-1}\right) \times 1000 /$ atomic weight $\left(\mathrm{g} \mathrm{mol}^{-1}\right)$. Atomic weights of Se and THg are $78.96 \mathrm{~g} \mathrm{~mol}^{-1}$ and $200.59 \mathrm{~g} \mathrm{~mol}^{-1}$, respectively. The calculated Se and THg
11 Kopstal; $12=$ Buderscheid; $13=$ Esch/Alzette; $14=$ Dippach; $15=$ Rossmillen. Raccoon (white circle): $16=$ Tarchamps; $17=$ Bech; $18=$ Winsler; $19=$ Junglister; $20=$ Marnach; $21=$ Roedt; 22 $=$ Bastendorf. b Germany. $1=$ Mücka; $2=$ City of Kassel; $3=$ Geislingen an der Stiege

concentrations were used to calculate Se:THg molar ratio (Kalisinska et al. 2017).

\section{Statistical analysis}

Statistical analyses were performed using Stat Soft Statistica 12.0 and Microsoft Excel 2016. Arithmetic means (AM), standard deviations of the AM (SD), median (Med), and minimum/maximum (ranges) were calculated. Distribution of empirical data on $\mathrm{THg}$ and Se concentrations in the hair of the studied animals diverged from the expected normal distribution, as shown by the Kolmogorov-Smirnov test with Lilliefors correction. Therefore, in comparisons of 
mean values of $\mathrm{THg}$ and $\mathrm{Se}$ concentration, nonparametric Mann-Whitney U tests were used. In addition, Spearman's rank correlation coefficients $(R)$ were calculated for the relations between THg levels, Se levels, and Se:THg molar ratio in the collected hair, and weight of the animals, as well as between the analyzed elements. Statistical significance was determined at $p<0.05$.

\section{Results}

The concentrations of $\mathrm{THg}$ and $\mathrm{Se}$, and Se:THg molar ratio in the hair of the raccoons and wildcats are presented in Table 1 . The total mercury levels were higher in hair from raccoons, but the difference was not statistically significant. The selenium concentrations were higher in the hair of raccoons than of wildcats. The $\mathrm{THg}$ concentration in the hair of raccoons from Luxembourg was almost $5 \times$ higher than raccoons from Germany. Se concentration was similar in animals from both countries. The molar ratio of Se:THg was $\sim 4 \times$ higher in the hair of the raccoons from Germany than those from Luxembourg.

Measured concentrations of analyzed elements and Se: THg molar ratio with respect to animal sex are presented in Table 2. The total mercury in hair of female wildcats was $\sim 1.4 \times$ higher than in male wildcats, and more than $2 \times$ higher in male raccoons than in female raccoons, but these differences were not statistically significant. Se concentration was similar in the hair of male and female wildcats as well as between male and female raccoons.

Significant negative correlation coefficients were found for the relationship between $\mathrm{THg}$ and Se:THg molar ratio in wildcats $(R=-0.97 ; p<0.05)$ and raccoons $(R=-0.93$; $p<0.05)$. There were no correlations in either wildcats or raccoons for $\mathrm{Se}-\mathrm{THg}$ or Se-Se:THg.

\section{Discussion}

Hair is a keratinaceous substance, rich in sulfhydrylcontaining amino acids that avidly bind certain trace elements. Mercury and selenium, in particular, have an affinity for the sulfur-rich amino acids in hair, and tend to be found in high concentrations there (Burger et al. 1994). Hair is commonly used to monitor trace element concentrations because it can easily be collected from both live and dead animals (Lord et al. 2002). Moreover, changes in trace elements in skin formations may reflect age-related changes in metabolic profiles across the life span and thus, may also be used to predict risk of age-related chronic diseases (Ambeskovic et al. 2013). Some researchers have found that hair $\mathrm{THg}$ levels are correlated with $\mathrm{THg}$ concentrations in the kidney and liver (Cumbie 1975; Halbrook et al. 1994); however, reports also exist to the contrary (Lord et al. 2002). Many studies have focused on measuring $\mathrm{Hg}$ concentration in the hair of piscivorous mammals such as the mink and otter (Table 3). In wild animal hair $\mathrm{Hg}$ occurs mainly as methylmercury and organic mercury comprising $80 \%$ and $20 \%$, respectively. There, $\mathrm{MeHg}$ is incorporated into the cornified epithelium during hair growth where it is not biologically available, but remains an indicator of previous levels of exposure (Wang et al. 2014).

Smaller mammals, such as mink, cats, otters, and raccoons appear to be more resistant to Hg than larger animals,

Table 1 The total mercury (THg) and selenium (Se) concentrations and Se:THg molar ratio in the hair of raccoons and wildcats from Germany and Luxembourg (AM arithmetic mean, Med median, SD standard deviation, U-Mann-Whitney $U$ test, $p$-level of significance, NS non-significant difference, $\mathrm{THg}$ and Se concentration are expressed in $\mathrm{mg} \mathrm{kg}^{-1} \mathrm{dw}$, molar concentration in brackets)

\begin{tabular}{llllll}
\hline & & THg & Se & Se:THg \\
\hline Raccoons & Total $(n=28)$ & AM \pm SD & $1.512 \pm 1.731(0.006 \pm 0.009)$ & $0.840 \pm 0.276(0.012 \pm 0.003)$ & $6.600 \pm 5.908$ \\
& & Med & $0.369(0.002)$ & $0.851(0.011)$ & 5.324 \\
& Range & $0.098-7.461(0.000-0.037)$ & $0.386-1.498(0.005-0.019)$ & $0.351-24.160$ \\
& \multirow{2}{*}{ Germany $(n=18)$} & AM \pm SD & $0.483 \pm 0.704(0.002 \pm 0.004)$ & $0.802 \pm 0.321(0.013 \pm 0.004)$ & $8.936 \pm 6.080$ \\
& Med & $0.221(0.001)$ & $0.747(0.009)$ & 7.630 \\
& Range & $0.098-2.805(0.000-0.014)$ & $0.386-1.498(0.005-0.019)$ & $0.416-24.160$ \\
& Luxembourg $(n=10)$ & AM \pm SD & $2.358 \pm 2.353(0.012 \pm 0.012)$ & $0.930 \pm 0.147(0.012 \pm 0.002)$ & $2.395 \pm 2.076$ \\
& Med & $1.508(0.008)$ & $0.922(0.012)$ & 1.967 \\
Wildcats & Range & $0.394-7.461(0.002-0.037)$ & $0.674-1.120(0.009-0.014)$ & $0.351-6.233$ \\
& Luxembourg $(n=15)$ & AM SD & $0.685 \pm 1.007(0.003 \pm 0.005)$ & $0.678 \pm 0.189(0.009 \pm 0.002)$ & $10.979 \pm 14.743$ \\
& Med & $0.273(0.001)$ & $0.641(0.008)$ & 4.037 \\
Raccoon vs. wildcats & Range & $0.035-3.669(0.000-0.018)$ & $0.338-1.026(0.004-0.013)$ & $0.427-49.735$ \\
Raccoon: Germany vs. Luxembourg & & NS & $U=17 p<0.001$ & $U=130 p<0.05$ & NS \\
\hline
\end{tabular}


Table 2 The total mercury (THg) and selenium (Se) concentrations and Se:THg molar ratio in hair of wildcat and raccoons according to the gender of animals (AM arithmetic mean, Med median, SD standard deviation, U-Mann-Whitney $U$ test, $p$-level of significance, NS non-significant difference; $\mathrm{THg}$ and Se concentration are expressed in $\mathrm{mg} \mathrm{kg}^{-1} \mathrm{dw}$; molar concentration in brackets)

\begin{tabular}{|c|c|c|c|c|c|}
\hline & & & $\mathrm{THg}$ & $\mathrm{Se}$ & Se:THg \\
\hline \multirow[t]{7}{*}{ Raccoon } & Male $(n=13)$ & $\mathrm{AM} \pm \mathrm{SD}$ & $1.667 \pm 2.331(0.008 \pm 0.012)$ & $0.803 \pm 0.323(0.010 \pm 0.004)$ & $5.289 \pm 5.244$ \\
\hline & & Med & $0.412(0.002)$ & $0.771(0.010)$ & 4.831 \\
\hline & & Range & $0.127-7.461(0.001-0.037)$ & $0.386-1.498(0.005-0.019)$ & $0.351-18.974$ \\
\hline & Female $(n=15)$ & $\mathrm{AM} \pm \mathrm{SD}$ & $0.706 \pm 0.812(0.004 \pm 0.004)$ & $0.887 \pm 0.232(0.011 \pm 0.003)$ & $7.736 \pm 6.385$ \\
\hline & & Med & $0.344(0.002)$ & $0.877(0.011)$ & 6.233 \\
\hline & & Range & $0.098-2.805(0.000-0.014)$ & $0.459-1.272(0.006-0.016)$ & $0.416-24.160$ \\
\hline & M vs. F & NS & NS & NS & \\
\hline \multirow[t]{7}{*}{ Wildcat } & Male $(n=9)$ & $\mathrm{AM} \pm \mathrm{SD}$ & $0.600 \pm 0.708(0.003 \pm 0.004)$ & $0.689 \pm 0.235(0.009 \pm 0.003)$ & $6.036 \pm 4.719$ \\
\hline & & Med & $0.273(0.001)$ & $0.642(0.008)$ & 4.037 \\
\hline & & Range & $0.124-2.196(0.001-0.011)$ & $0.338-1.026(0.004-0.013)$ & $1.026-15.480$ \\
\hline & Female $(n=6)$ & $\mathrm{AM} \pm \mathrm{SD}$ & $0.812 \pm 1.416(0.004 \pm 0.007)$ & $0.661 \pm 0.105(0.008 \pm 0.001)$ & $18.394 \pm 21.518$ \\
\hline & & Med & $0.296(0.001)$ & $0.647(0.008)$ & 8.166 \\
\hline & & Range & $0.035-3.669(0.000-0.018)$ & $0.509-0.788(0.006-0.010)$ & $0.427-49.735$ \\
\hline & $\mathrm{M}$ vs. $\mathrm{F}$ & NS & NS & NS & \\
\hline
\end{tabular}

likely due to differences in the rate of metabolism and a higher rate of detoxification (Eisler 2006; Lanocha et al. 2014). It has been estimated that THg concentrations ranging from 1 to $5 \mathrm{mg} \mathrm{kg}^{-1}$ in the hair of piscivorous mammals represent normal background levels (Sheffy and St. Amant 1982). Based on a literature review, the US Fish and Wildlife Service proposed that a level of $1.1 \mathrm{mg} \mathrm{kg}^{-1} \mathrm{ww}$ $\left(5.5 \mathrm{mg} \mathrm{kg}^{-1} \mathrm{dw}\right)$ in hair and organs with central roles in detoxification "should be considered as presumptive evidence of an environmental mercury problem" (Eisler 2000; Lanocha et al. 2014). Moreover, hair THg levels of $30 \mathrm{mg}$ $\mathrm{kg}^{-1}$ have been identified as the lowest observed adverse effect level (LOAEL) for terrestrial mammalian wildlife (Basu et al. 2007; Crowley et al. 2018; Evers et al. 2007).

Ecotoxicological studies with raccoons, conducted mainly in North America, have examined mainly the liver, kidney, and, less frequently, the hair (Lanocha et al. 2014; Lord et al. 2002; Porcella et al. 2004; Souza et al. 2013). Literature shows hair $\mathrm{THg}$ levels in piscivorous mammals, such as the raccoon, ranging from $\sim 0.3$ to $\sim 13 \mathrm{mg} \mathrm{kg}^{-1} \mathrm{dw}$ (Table 3). In this study, average THg concentration in raccoons was $1.5 \mathrm{mg} \mathrm{kg}^{-1} \mathrm{dw}$, similar to that reported by Lord et al. (2002) in the hair of raccoons from the U.S. Department of Energy's Savannah River Site Steel Creek delta, an area heavily polluted with $\mathrm{Hg}$ compounds. In our study, the highest THg levels $\left(\sim 7.5 \mathrm{mg} \mathrm{kg}^{-1} \mathrm{dw}\right)$ were found in raccoons from the forested and agricultural areas near Junglinster, Luxembourg. Increased concentrations of various elements in the fields, including organic forms of $\mathrm{Hg}$, may possibly lead to changes in animal organ function, thus increasing tissue Hg levels (Strickman and Mitchell 2017).
We have not found existing reports on levels of trace elements in the hair of European wildcats. Measured THg in felids in non-contaminated areas does not exceed $30 \mathrm{mg} \mathrm{kg}^{-1}$ dw (May Júnior et al. 2017), while in contaminated areas it ranges from 46 to $673 \mathrm{mg} \mathrm{kg}^{-1} \mathrm{dw}$ (Kitamura 1968; May Júnior et al. 2017). In this study, average THg concentration in European wildcats was $0.73 \mathrm{mg} \mathrm{kg}^{-1} \mathrm{dw}$, about $40 \mathrm{x}$ lower than in the hair of jaguars from a reference area in Brazil. The highest observed THg content in feline hair was recorded in jaguars from a region affected by gold mining and $\mathrm{Hg}$ contamination (May Júnior et al. 2017).

Although Se plays an important role in hair growth, little is known about its levels in skin formations. Hair, similar to bone tissue, may reflect the long-term Se level in the organism. Selenium-deficient rat pups display a slower growth rate and sparse hair growth (Bates et al. 2000). Sengupta et al. (2010) credit selenoproteins for the protective roles of selenium in skin and establish that deficiencies in selenoproteins beget most skin abnormalities associated with selenium deficiency. In raccoon hair, Se may be excreted at a higher rate than in other animals (Souza et al. 2013). In our study, hair median Se levels in the raccoon and European wildcat were 0.851 and $0.641 \mathrm{mg} \mathrm{kg}^{-1} \mathrm{dw}$, respectively, a statistically significant difference. Higher Se concentration in raccoon hair was likely a result of higher absorption of plant Se, resulting from a diet containing a significant amount of plants.

Selenium concentration similar to that found in the present study was noted by Clark et al. (1989) in the hair of raccoons from and area known to have a low Se concentration (Volta Wildlife Area, California, USA). They 


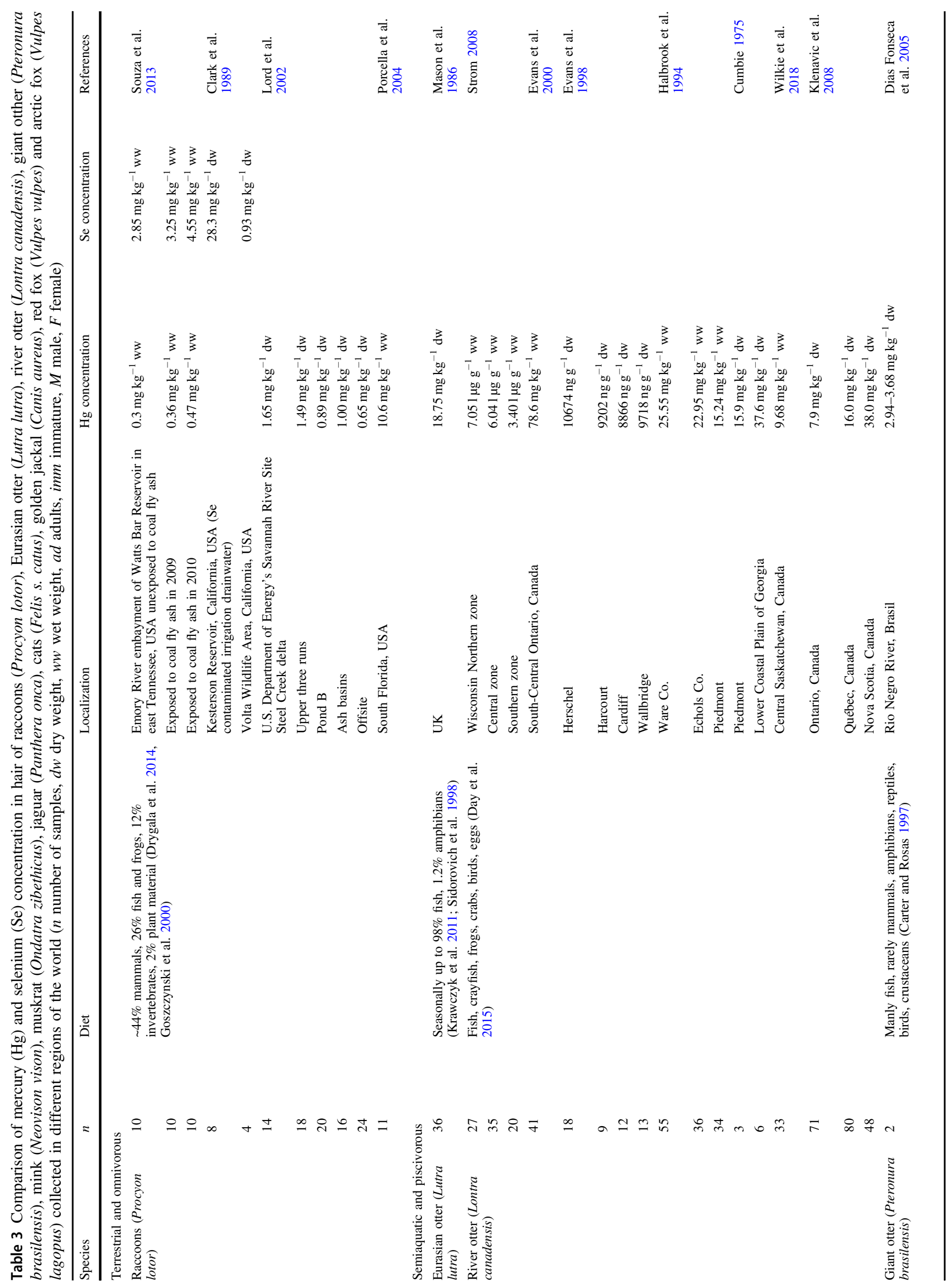




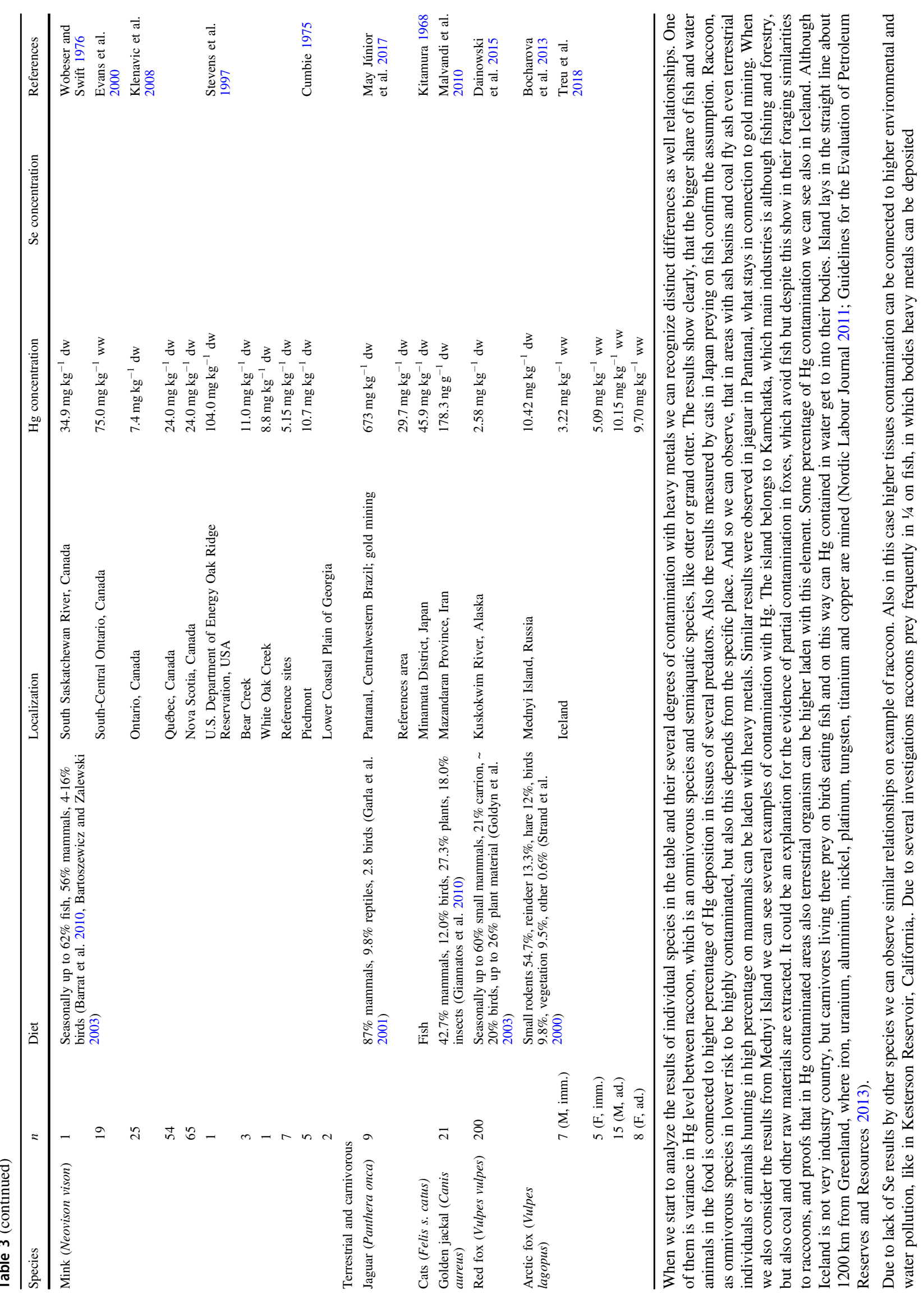


found much higher Se levels ( $28.3 \mathrm{mg} \mathrm{kg}^{-1} \mathrm{dw}$ ) in raccoon hair from an Se-contaminated irrigation drain water zone (Kesterson Reservoir, California, USA). The lower Se concentrations in the raccoons and wildcats in our study may result from naturally low soil Se levels in Germany and Luxembourg (Reimann et al. 2014).

Levels of toxic elements, including $\mathrm{Hg}$, in the hair, may be affected by biotic and abiotic factors including age, sex, sampling season, and feeding strategy (Treu et al. 2018). In the present study, no differences were found in $\mathrm{THg}$ and Se concentrations between male and female raccoons or European wildcats. This confirms the results of previous studies showing no sex-dependence of $\mathrm{Hg}$ concentration in the hair of cats (Sakai et al. 1995) and mink (Stevens et al. 1997). In contrast, a sex-related difference was observed in previous studies on the raccoon (Porcella et al. 2004) and panther (Newman et al. 2005).

Concentrations of elements in hair also depend on the physiological, hormonal, and individual characteristics of the species. The binding of trace elements to hair-forming proteins depends on the amount of protein, carbohydrates, and lipids supplied, as well as the penetration of these elements into cells through diet and their use in metabolic processes (Baumgartner et al. 1981). The raccoon diet consists mainly of a variety of molluscs, fish, amphibians, insects, birds, vegetables, and fruits, with some carrion and garbage (Bartoszewicz et al. 2008). The European wildcat is a medium-sized carnivore, preying on rodents, insectivores, lagomorphs, reptiles, insects, and eating some plants (Lozano et al. 2006; Moleon and Gil-Sanchez 2003; Sarmento 1996). These dietary differences are likely responsible for the observed discrepancy between the concentrations of the investigated elements in the hair of these two animals.

Many reports stress the value of not only determining concentrations of $\mathrm{Hg}$ and $\mathrm{Se}$, but also examining their molar ratio in wildlife. Tissue Se:THg molar ratios of $<1$ may be connected with a potential increase in $\mathrm{Hg}$ toxicity. In warm blooded animals (specifically marine species), an important detoxification mechanism relies on the antagonistic impact of Se on Hg. Kalisinska et al. (2017) suggested that piscivores in Se-deficient areas are more exposed to $\mathrm{Hg}$ than fish and omnivores, further exacerbating the effect of this deficiency. Moreover, in the raccoons from Warta Mouth National Park (Poland), an area with moderate Hg pollution, it was found that Se:THg molar ratios in muscle spanned a wide range, from 0.73 to $\sim 66$. Data on $\mathrm{Hg}$, Se, and Se:THg ratios in terrestrial mammals are limited. In the present study, Se:THg ratio in raccoon hair (Luxembourg and Germany) ranged from 0.351 to 24.16 , and in wildcats (Luxembourg) it ranged from 0.427 to 41.11 . In some individual specimens, the hair Se:THg molar ratio was $<1$, which could enhance THg toxicity. However, in most cases these values exceeded 1 , thus likely effectively protecting against the adverse effects of $\mathrm{Hg}$.

Some authors suggest that the molar ratio of $\mathrm{Se}: \mathrm{Hg}$ in warm-blooded vertebrate tissues depends on the trophic group and species of the animal, the type of tissue being examined, and the area from which the animals came (Burger and Gochfeld 2013). In the presented study, statistically significant differences were found in Se:THg ratio between raccoon hair from Germany and from Luxembourg.

The highest exposure to $\mathrm{Hg}$ is recorded in piscivorous animals, with Se:THg molar ratio in the organs of otters and minks not exceeding 1 (Kalisinska et al. 2017; Wren 1984). Our study suggests that omnivorous raccoons and predatory wildcats are less exposed to the toxic effects of $\mathrm{Hg}$, likely due to a smaller share of fish in their diet, the main source of mercury for these animals, the rate of $\mathrm{Hg}$ absorption, and considerable intake of easily digestible Se from plants $(50 \%)$ or meat $(35 \%)$. It should be noted however, that regardless of species, $\mathrm{Hg}$-polluted and Se-deficient areas may influence the $\mathrm{Se}: \mathrm{Hg}$ ratio, possibly leading to toxic effects in wild mammals.

\section{Conclusions}

Analysis of the concentration of THg, Se and Se:THg molar ratio in the hair of raccoons (Procyon lotor) and European wildcats (Felis s. silvestris) from Germany and Luxembourg showed that: $\mathrm{THg}$ concentration was almost $5 \times$ higher in raccoons from Luxembourg than from Germany. Selenium concentration was significantly higher in raccoons than in wildcats. Sex does not influence the concentration of $\mathrm{THg}$ and $\mathrm{Se}$ in the hair of raccoons or European wildcats. Average $\mathrm{Se}: \mathrm{THg}$ ratio was $>1$ in studied animals, which indicates that omnivorous raccoons and predatory wildcats are less exposed to the toxic effects of $\mathrm{THg}$ than piscivorous animals.

Acknowledgements We would like to thank H. Ansorge, G. Biver, F. Daems, L. Dondelinger, C. Felten, M. Gaston, D. Grosbusch, J. M. Guinet, S. Hermes, F. Hoss, M. Jans, D. Jeschke, J. Junck, M. Kugener, J. Lang, H. Matzke, X. Mestdagh, M. Moes, J. P. Pir, M. Ronkaz, R. Schauls, L. Schley, G. Schmidt, S. Schneider, F. Schoos, M. Schulz, F. Sowa, R. Stranen and F. Wolff for providing us with wildcat an raccoons carcasses and Fondation faune-flore for supporting the project.

\section{Compliance with ethical standards}

Conflict of interest The authors declare that they have no conflict of interest.

Ethics statement All wildcats from Luxembourg had been previously killed by motor vehicles and were collected with the authorisation of the Luxembourg Ministry of Sustainable Development and 
Infrastructures (Ref.: $70646 \mathrm{GW} / \mathrm{sc}$ ). As an invasive species, raccoons are not legally protected in Luxembourg or Germany and can be harvested by licensed hunters outside the closed season without special permission. No animal was killed with the aim of providing samples for this study. All hunted individuals were legally shot and made available to the authors.

Publisher's note Springer Nature remains neutral with regard to jurisdictional claims in published maps and institutional affiliations.

Open Access This article is distributed under the terms of the Creative Commons Attribution 4.0 International License (http://crea tivecommons.org/licenses/by/4.0/), which permits unrestricted use, distribution, and reproduction in any medium, provided you give appropriate credit to the original author(s) and the source, provide a link to the Creative Commons license, and indicate if changes were made.

\section{References}

Ahsan U, Kamran Z, Raza I et al. (2014) Role of selenium in male reproduction-a review. Anim Reprod Sci 146:55-62. https://doi. org/10.1016/j.anireprosci.2014.01.009

Ambeskovic M, Fuchs E, Beaumier P et al. (2013) Hair trace elementary profiles in aging rodents and primates: links to altered cell homeodynamics and disease. Biogerontology 14:557-567. https://doi.org/10.1007/s10522-013-9464-1

Bartoszewicz M, Okarma H, Zalewski A et al. (2008) Ecology of the raccoon (Procyon lotor) from western Poland. Ann Zool Fennici 45:291-298

Barrat J, Richomme C, Moinet M (2010) The accidental release of exotic species from breeding colonies and zoological collections. Rev Sci Tech Int Epizoot 29:113-122

Bartoszewicz M, Zalewski A (2003) American mink, Mustela vison diet and predation on waterfowl in the Słońsk Reserve, western Poland. Folia Zool 2:225-238

Basu N, Scheuhammer AM, Bursian SJ et al. (2007) Mink as a sentinel species in environmental health. Environ Res 103:130-144. https://doi.org/10.1016/j.envres.2006.04.005

Bates JM, Spate VL, Morris JS et al. (2000) Effects of selenium deficiency on tissue selenium content, deiodinase activity, and thyroid hormone economy in the rat during development. Endocrinology 141:2490-2500. https://doi.org/10.1210/endo.141.7.7571

Baumgartner A, Jones P, Black C (1981) Detection of phencyclidine in hair. J Forensic Sci 26:576-581

Beau F, Bustamante P, Michaud B et al. (2019) Environmental causes and reproductive correlates of mercury contamination in European pond turtles (Emys orbicularis). Environ Res 172:338-344. https://doi.org/10.1016/j.envres.2019.01.043

Bigler WJ, Jenkins JH, Cumbie PM et al. (1975) Wildlife and environmental health: raccoons as indicators of zoonoses and pollutants in Southeastern United States. J Am Vet Med Assoc 167:592-597

Biró Z, Szemethy L, Heltai M (2004) Home range sizes of wildcats (Felis silvestris) and feral domestic cats (Felis silvestris f. catus) in a hilly region of Hungary. Mamm Biol 69:302-310

Bjerregaard P, Fjordside S, Hansen MG et al. (2011) Dietary selenium reduces retention of methyl mercury in freshwater fish. Environ Sci Technol 45:9793-9798. https://doi.org/10.1021/es202565g

Bjørklund G, Aaseth J, Ajsuvakova OP et al. (2017) Molecular interaction between mercury and selenium in neurotoxicity. Coord Chem Rev 332:30-37. https://doi.org/10.1016/j.ccr.2016. 10.009
Bocharova N, Treu G, Czirják GÁ et al. (2013) Correlates between feeding ecology and mercury levels in historical and modern arctic foxes (Vulpes lagopus). PLoS ONE 8:e60879. https://doi. org/10.1371/journal.pone.0060879

Boscher A, Gobert S, Guignard C et al. (1996) Biosphärenreservates Oberlausitzer Heide — und Teichlandschaft. Biosphärenreservatsplan Teil 1. Grundlagen für Schutz, Pflege und Entwicklung, Mücka

Burger J, Gochfeld M (2013) Selenium/mercury molar ratios in freshwater, marine, and commercial fish from the USA: variation, risk, and health management. Rev Environ Health 28:129-143. https://doi.org/10.1515/reveh-2013-0010

Burger J, Marquez M, Gochfeld M (1994) Heavy metals in the hair of opossum from Palo Verde, Costa Rica. Arch Environ Contam Toxicol 27:472-476

Carter SK, Rosas FC (1997) Biology and conservation of the giant otter Pteronura brasiliensis. Mamm Rev 27:1-26

Castellini J, Rea LD, Lieske CL et al. (2012) Mercury concentrations in hair from neonatal and juvenile Steller Sea Lions (Eumetopias jubatus): implications based on age and region in this northern Pacific marine sentinel piscivore. EcoHealth 9:267-277. https:// doi.org/10.1007/s10393-012-0784-4

Castoldi AF, Coccini T, Ceccatelli S et al. (2001) Neurotoxicity and molecular effects of methylmercury. Brain Res Bull 55:197-203

Cho JM, Yang HR (2018) Hair mineral and trace element contents as reliable markers of nutritional status compared to serum levels of these elements in children newly diagnosed with inflammatory bowel disease. Biol Trace Elem Res 185:20-29. https://doi.org/ 10.1007/s12011-017-1225-6

Clark Jr DR, Ogasawara PA, Smith GJ et al. (1989) Selenium accumulation by raccoons exposed to irrigation drainwater at Kesterson National Wildlife Refuge, California, 1986. Arch Environ Contam Toxicol 18:787-794

Crowley SM, Hodder DP, Johnson CJ et al. (2018) Wildlife health indicators and mercury exposure: a case study of river otters (Lontra canadensis) in central British Columbia, Canada. Ecol Indic 89:63-73. https://doi.org/10.1016/j.ecolind.2018.01.061

Cumbie PM (1975) Mercury in hair of bobcats and raccoons. J Wildl Manag 39:419-425

Curi NH, Brait CH, Antoniosi Filho NR et al. (2012) Heavy metals in hair of wild canids from the Brazilian Cerrado. Biol Trace Elem Res 147:97-102. https://doi.org/10.1007/s12011-011-9303-7

Cuvin-Aralar ML, Furness RW (1991) Mercury and selenium interaction: a review. Ecotoxicol Environ Saf 21:348-364

Dainowski BH, Duffy LK, McIntyre J et al. (2015) Hair and bone as predictors of tissular mercury concentration in the western Alaska red fox, Vulpes vulpes. Sci Total Environ 518-519:526-533. https://doi.org/10.1016/j.scitotenv.2015.03.013

Davis LE, Kornfeld M, Mooney HS et al. (1994) Methylmercury poisoning: long-term clinical, radiological, toxicological, and pathological studies of an affected family. Ann Neurol 35:680-688

Day CC, Westover MD, McMillan BR (2015) Seasonal diet of the northern river otter (Lontra canadensis): what drives prey selection? Can J Zool 93:197-205. https://doi.org/10.1139/cjz2014-0218

Dias Fonseca FR, Malm O, Francine Waldemarin H (2005) Mercury levels in tissues of Giant otters (Pteronura brasiliensis) from the Rio Negro, Pantanal, Brazil. Environ Res 98:368-371

Drygala F, Wernerb U, Zoller H (2014) Diet composition of the invasive raccoon dog (Nyctereutes procyonoides). Hystrix 24:190-194

Eisler R (2000) Handbook of chemical assessment: health hazards to humans, plants and animals, vol I. Lewis, Washington, DC, USA

Eisler R (2006) Mercury hazards to living organisms. CRC Press, Boca Raton, FL 
Evans RD, Addison EM, Villeneuve JY et al. (1998) An examination of spatial variation in mercury concentrations in otter (Lutra canadensis) in south-central Ontario. Sci Total Environ 213:239-245

Evans RD, Addison EM, Villeneuve JY et al. (2000) Distribution of inorganic and methylmercury among tissues in mink (Mustela vison) and otter (Lutra canadensis). Environ Res Sect A 84:133-139

Evers DC, Han YJ, Driscoll CT et al. (2007) Biological mercury hotspots in the Northeastern United State and Southeastern Canada. BioScience 57:29-43. https://doi.org/10.1641/B570107

Fordyce FM (2013) Selenium deficiency and toxicity in the environment. Essent of Med Geol 375-416

Garla RC, Setz EF, Gobbi N (2001) Jaguar (Panthera onca) food habits in Atlantic Rain Forest of southeastern Brazil. Biotropica 33:691-696. https://doi.org/10.1111/j.17447429.2001.tb00226.x

Giannatos G, Karypidou A, Legakis A, Polymeni R (2010) Golden jackal (Canis aureus L.) diet in Southern Greece. Mamm Biol 75:227-232. https://doi.org/10.1016/j.mambio.2009.03.003

Goldyn B, Hromada M, Surmacki A, Tryjaowski P (2003) Habitat use and diet of the red fox Vulpes vulpes in an agricultural landscape in Poland. Z Jagdwiss 49:191-200

Goszczynski J, Jedrzejewska B, Jedrzejewski W (2000) Diet composition of badgers (Meles meles) in a pristine forest and rural habitats of Poland compared to other European populations. J Zool Lond 250:495-505

Górski K, Kondracki S, Saba L (2018) Selenium concentration in soil, and in the feed and hair coat of Polish Holstein-Friesian cows administered a mineral mixture. Indian J Anim Sci 88:1207-1210

Greenland's red hot labour market, Nordic Labour Journal, 2011

Society of petroleum engineers (2013) Guidelines for the evaluation of petroleum reserves and resources. Society of petroleum engineers

Graeme KA, Pollack Jr CV (1998) Heavy metal toxicity, Part I: arsenic and mercury. J Emerg Med 16:45-56

Halbrook RS, Jenkins JH, Bush PB et al. (1994) Sublethal concentrations of mercury in river otters: monitoring environmental contamination. Arch Environ Contam Toxicol 27:306-310

Herbert GB, Peterle TJ (1990) Heavy metal and organochlorine compound concentrations in tissues of raccoons from east-central Michigan. Bull Environ Contam Toxicol 44:331-338

Herrmann M, Kitchener A, Meinig H et al. (2007) Felis silvestris. The IUCN red list of threatened species 2007:e. T60354712A112955994, https://www.iucnredlist.org/species/ $60354712 / 112955994$

Izquierdo A, Casas C, Herrero E (2010) Selenite-induced cell death in Saccharomyces cerevisiae: protective role of glutaredoxins. Microbiology 156:2608-2620. https://doi.org/10.1099/mic.0.039719-0

Kalisińska E (2019) Endothermic animals as biomonitors of terrestrial environments. In: Kalisińska E (ed) Mammals and birds as bioindicators of trace element contaminations in terrestrial environments. An ecotoxicological assessment of the northern hemisphere. Springer, Cham, p 21-53

Kalisinska E, Lanocha-Arendarczyk N, Kosik-Bogacka D et al. (2017) Muscle mercury and selenium in fishes and semiaquatic mammals from a selenium-deficient area. Ecotoxicol Environ Saf 136:24-30. https://doi.org/10.1016/j.ecoenv.2016.10.028

Khan WA, Wang F (2010) Chemical demethylation of methylmercury by selenoamino acids. Chem Res Toxicol 23:1202-1206. https:// doi.org/10.1021/tx100080s

Kitamura S (1968) Determination of mercury content in bodies of inhabitants, cats, fishes, and shells in Minamata District and in the mud of Minamata Bay. In: Kitsuna M (ed) Minamata disease. Kumamoto University Press, Kumamoto, Japan, p 257-266

Klar N, Fernández N, Kramer-Schadt S et al. (2008) Habitat selection models for European wildcat conservation. Biol Conserv 141:308-319. https://doi.org/10.1016/j.biocon.2007.10.004
Klenavic K, Champoux L, Mike O et al. (2008) Mercury concentrations in wild mink (Mustela vison) and river otters (Lontra canadensis) collected from eastern and Atlantic Canada: relationship to age and parasitism. Environ Pollut 156:359-366. https://doi.org/10.1016/j.envpol.2008.02.003

Krawczyk AJ, Skierczyński M, Tryjanowski P (2011) Diet of the Eurasian otter Lutra lutra on small watercourses in western Poland. Mammalia 75:207-210

Lailson-Brito J, Cruz R, Dorneles PR et al. (2012) Mercury-selenium relationships in liver of Guiana dolphin: the possible role of Kupffer cells in the detoxification process by tiemannite formation. PLoS ONE 7:e42162. https://doi.org/10.1371/journal.pone. 0042162

Lanocha N, Kalisinska E, Kosik-Bogacka DI et al. (2014) Mercury levels in raccoons (Procyon lotor) from the Warta Mouth National Park, northwestern Poland. Biol Trace Elem Res 159:152-160. https://doi.org/10.1007/s12011-014-9962-2

Lieske CL, Moses SK, Castellini J et al. (2011) Toxicokinetics of mercury in blood compartments and hair of fish-fed sled dogs. Acta Vet Scand 53:66. https://doi.org/10.1186/1751-0147-53-66

Lord CG, Gaines KF, Boring CS et al. (2002) Raccoon (Procyon lotor) as a bioindicator of mercury contamination at the U.S. Department of Energy's Savannah River Site. Arch Environ Contam Toxicol 43:356-363

Lozano J, Moleo M, Virgo E (2006) Biogeographical patterns in the diet of the wildcat, Felis silvestris Schreber, in Eurasia: factors affecting the trophic diversity. J Biogeogr 33:1076-1085. https:// doi.org/10.1111/j.1365-2699.2006.01474.x

Malvandi H, Ghasempouri SM, Esmaili-Sari A et al. (2010) Evaluation of the suitability of application of golden jackal (Canis aureus) hair as a noninvasive technique for determination of body burden mercury. Ecotoxicology 19:997-1002. https://doi.org/10. 1007/s10646-010-0504-1

Mao J, Pop VJ, Bath SC et al. (2016) Effect of low-dose selenium on thyroid autoimmunity and thyroid function in UK pregnant women with mild-to-moderate iodine deficiency. Eur J Nutr 55:55-61. https://doi.org/10.1007/s00394-014-0822-9

Mason CF, Last NI, Macdonald SM (1986) Mercury, cadmium, and lead in British otters. Bull Environ Contam Toxicol 37:844-849

May Júnior JA, Quigley H, Hoogesteijn R et al. (2017) Mercury content in the fur of jaguars (Panthera onca) from two areas under different levels of gold mining impact in the Brazilian Pantanal. Acad Bras Cienc 90:2129-2139. https://doi.org/10. 1590/0001-3765201720170190

Moleon M, Gil-Sanchez JM (2003) Food habits of the wildcat (Felis silvestris) inapeculiar habitat: the Mediterranean high mountain. $\mathrm{J}$ Zool Lond 260:17-22. https://doi.org/10.1017/S0952836902003370

Newman J, Zillioux E, Rich E et al. (2005) Historical and other patterns of monomethyl and inorganic mercury in the Florida panther (Puma concolor coryi). Arch Environ Contam Toxicol 48:75-80

Nowak R (1997) Walker's Mammals of the World. The Johns Hopkins University Press, Baltimore. http://www.press.jhu.edu/books/wa lkers_mammals_of_the_world/carnivora/carnivora.felidae.felis. html. Accessed 12 Mar 2004

Ohlendorf HM, Heinz GH (2011) Selenium in birds, Chapter 21. In: Beyer WN, Meador JP (eds) Environmental contaminants in biota: interpreting tissue concentrations. CRC Press, Boca Raton, FL, USA, p 669-701

Pierpaoli M, Biro ZS, Herrmann M et al. (2003) Genetic distinction of wildcat (Felis silvestris) populations in Europe, and hybridization with domestic cats in Hungary. Mol Ecol 12:2585-2598. https:// doi.org/10.1046/j.1365-294X.2003.01939.x

Pilarczyk P, Tomza-Marciniak A, Pilarczyk R, Marciniak A, Bąkowska M, Nowakowska E (2019) Selenium, Se. In: Kalisińska E (ed) Mammals and birds as bioindicators of trace 
element contaminations in terrestrial environments. An ecotoxicological assessment of the Northern Hemisphere. Springer, Cham, p 301-362

Pilarczyk B, Tomza-Marciniak A, Mituniewicz-Małek A (2010) Selenium content in selected products of animal origin and estimation of the degree of cover daily Se requirement in Poland. Int J Food Sci Technol 4:186-191. https://doi.org/10.1111/j.13652621.2009.02120.x

Porcella DB, Zillioux EJ, Grieb TM et al. (2004) Retrospective study of mercury in raccoons (Procyon lotor) in south Florida. Ecotoxicology 13:207-221

Qazi IH, Angel C, Yang H et al. (2018) Selenium, selenoproteins, and female reproduction: a review. Molecules 23:E3053. https://doi. org/10.3390/molecules 23123053

Raymond LJ, Ralston NV (2004) Mercury: selenium interactions and health implications. SMDJ Seychelles Med. Dental J 17:72-77

Rea LD, Correa L, Castellini J et al. (2013) Maternal Steller sea lion diets elevate fetal mercury concentrations in an area of population decline. Sci Total Environ 454-455:277-282. https://doi.org/10. 1016/j.scitotenv.2013.02.095

Reimann C, Birke M, Demetriades A, Filzmoser P, O'Connor P (eds) (2014) Chemistry of Europe's agricultural soils-Part B: general background information and further analysis of the GEMAS data set. Geologisches Jahrbuch (Reihe B 103), Schweizerbarth, Hannover

Rhymer JM, Simberloff D (1996) Extinction by hybridization and introgression. Annu Rev Ecol Evol Syst 27:83-109

Roman M, Jitaru P, Barbante C (2014) Selenium biochemistry and its role for human health. Metallomics 6:25-54. https://doi.org/10. $1039 / \mathrm{c} 3 \mathrm{mt} 00185 \mathrm{~g}$

Sakai T, Ito M, Aoki H et al. (1995) Hair mercury concentrations in cats and dogs in central Japan. Br Vet J 151:215-219

Sarmento P (1996) Feeding ecology of the European wildcat Felis silvestris in Portugal. Acta Theriol 41:409-414

Scheuhammer AM, Meyer MW, Sandheinrich MB et al. (2007) Effects of environmental methylmercury on health of wild birds, mammals, and fish. Ambio 36:12-18

Sengupta A, Lichti UF, Carlson BA et al. (2010) Selenoproteins are essential for proper keratinocyte function and skin development. PLoS ONE 5:e12249. https://doi.org/10.1371/journal.pone. 0012249

Sheffy TB, St Amant JR (1982) Mercury burdens in furbearers in Wisconsin. J Wildl Manag 46:1117-1120

Sidorovich V, Kruuk H, Macdonald D, Maran T (1998) Diets of semiaquatic carnivores in northern Belarus, with implications for population changes. Altitude and European Otter ekology, Cambridge University Press, p 177-189

Silva EF, Missio D, Martinez CS et al. (2019) Mercury at environmental relevant levels affects spermatozoa function and fertility capacity in bovine sperm. J Toxicol Environ Health Part A 82:268-278. https://doi.org/10.1080/15287394.2019.1589608
Stevens RT, Ashwood TL, Sleeman JM (1997) Mercury in hair of muskrats (Ondatra zibethicus) and mink (Mustela vison) from the U. S. Department of Energy Oak Ridge Reservation. Bull Environ Contam Toxicol 58:720-725

Soares de Campos M, Sarkis JE, Müller RC, Brabo E, Santos E (2002) Correlation between mercury and selenium concentrations in Indian hair from Rondônia State, Amazon region, Brazil. Sci Total Environ 287:155-161

Souza MJ, Ramsay EC, Donnell RL (2013) Metal accumulation and health effects in raccoons (Procyon lotor) associated with coal fly ash exposure. Arch Environ Contam Toxicol 64:529-536. https:// doi.org/10.1007/s00244-012-9865-1

Sahl P, Artois M (1994) Status and conservation of the wildcat (Felis silvestris) in Europe and around the Mediterranean rim. Nature and Environment Series, No 69. Council of Europe Press, Strasbourg, p 78

Strand O, Landa A, Linnell JD, Zimmermann B, Skogland T (2000) Social organization and parental behaviour in arctic foxes, Alopex lagopus. J Mammal 81:223-233

Strickman RJ, Mitchell CP (2017) Accumulation and translocation of methylmercury and inorganic mercury in Oryza sativa: An enriched isotope tracer study. Sci Total Environ 574:1415-1423. https://doi.org/10.1016/j.scitotenv.2016.08.068

Strom SM (2008) Total mercury and methylmercury residues in river otters (Lutra canadensis) from Wisconsin. Arch Environ Contam Toxicol 54:546-554

Stubbe M (1993) Procyon lotor (Linnaeus, 1758). In: Stubbe M, Krapp F (eds), Handbuch des Saugetiere Europas, vol 5/I. Akademische Verlagsgesellschaft, Wiesbaden, p 331-364

Thomson CD (2004) Assessment of requirements for selenium and adequacy of selenium status: a review. Eur J Clin Nutr 58:391-402

Treu G, Krone O, Unnsteinsdóttir ER et al. (2018) Correlations between hair and tissue mercury concentrations in Icelandic arctic foxes (Vulpes lagopus). Sci Total Environ 619-620:1589-1598. https://doi.org/10.1016/j.scitotenv.2017.10.143

Wang W, Evans RD, Hickie BE et al. (2014) Methylmercury accumulation and elimination in mink (Neovison vison) hair and blood: results of a controlled feeding experiment using stable isotope tracers. Environ Toxicol Chem 33:2873-2880. https://doi. org/10.1002/etc. 2762

Wiener JG, Krabbenhoft DP, Heinz GH et al. (2003) Ecotoxicology of mercury. In: Hoffman DJ, Rattner BA, Burton GA, Cairns J (eds) Handbook of ecotoxicology. Lewis, Boca Raton, p 409-463

Wilkie SC, Espie RH, Basu N et al. (2018) Trapped river otters (Lontra canadensis) from central Saskatchewan differ in total and organic mercury concentrations by sex and geographic location. FACETS 3:139-154. https://doi.org/10.1139/facets-2017-0082

Wobeser G, Swift M (1976) Mercury poisoning in a wild mink. J Wildl Dis 12:335-340

Wren CD (1984) Distribution of metals in tissues of beaver, raccoon and otter from Ontario, Canada. Sci Total Environ 34:177-184 